energetic direction of another modical officor of the Board, Sir Arthur Nowsholme, the first State social health servicos wero foundod.

'This is a valuable and excellont biography of one of England's groatost benefactors. ArTHUR MaoNALTY

\section{TREATMENT OF CANCER}

\section{Biotherapy of Malignant Tumours}

By N. (*. Klyuyova and G. I. Roskin. Translatod from the Russian by J. J. Oliver. 'Translation edited by Dr. W. J. P. Neish. Pp. ix $+315+132$ platos. (London and Now York, Porgamon Press, 1963.) $80 s$.

GINCE tho aarly work of Coloy at the end of the nineD teerith century, reports have froquently appeared suggesting that the growth and developmont of malignant diseaso may bo modifiod significantly by certain intor. current infections or by various microbial products. In recont times numerous low molecular weight products of microbiological origin have been isolated, chomically characterized and shown to havo oarcinostatic properties in animals and in man. These relativoly simplo substancos are, howevor, only part of a much broader spoctrum of natural products to the thorapoutio use of which the authors of this Russian work apply the gonoral term "Biothernpy". Within this definition they include the use of such diverse agonts as viable micro-organisms pathogenic or otherwise, microbial toxins, lysatos and filtratos, oncolytic viruses, bacteriophage, yeast and fungal products and rolated mibtorials of groater complexity and less well defined than the simplo carcinostatic antibiotics. The proliminary chapters of the book are dovotod to briof reviews of these topios, reviows which in many instances aro out-dated at the presont timo duo to tho six-year delay that has oecurred between the publication of the original Russian toxt and the appoaraneo of its translation.

A primary object of this book is to presont tho oxperionce that the authors and their clinical colleagues accruod over the period 1946-57 in tho use of Trypanosoma cruzi oxtracts (oruzin) in the treatment of human cancers, particularly of the lip and broast. This they have done by way of detailed caso reports supplementod in tho English translation by a selection of the results obtainod more recently by Fronoh investigators utilizing similar Trypanosomal products. The anthors elaim that complote regression can bo induced in a proportion of human malignaneios of varions typos and localization by prolonged administration of the extracts and that tho treatmont can be offective against primary, secondary and recurront growths with no detoctable pathological effect on the function or structure of normal tissucs. In cases of advancod inoperablo disoase, a transition to an operable condition may occasionally ariso and likewise, where possible, surgical intervention during the courso of trostmont may accelerato the process of oncolysis.

In subsequent chapters the authors describe the histological and cytological changes indueod in malignant tissues of both human and animal origin under the influenen of T. cruzi extracts. They describe a complex series of changes in tho growth characteristics of tumour tissues in which the cells undergo progossive diminution in nuclnar and nucleolar sizes, in mitotic activity, in ribonucleic acid contont and protoin synthesizing ability. They believe that this process of 'normalization' and 'loss of iggressivonoss' leads to the establishment of a now relationship betwoon orstwhilo malignant tissue and the normal body defence mochanisms. Subjoet to the degree to which this process can be established, there follows a subsequent reaction in which the tumour region is invaded by calls of the reticulo-ondotholial system leading to the destruction of tumour cells and their replacemont by connective tissuo as tho final act of tho carcinolytic process whore this goes to completion.
To the exporimontnlist, it is porhaps unfortunate that much of the earlier work leading to the prosent elinical investigation was published in a volume under the same title by the authors in 1946 and will not be readily a vailable to Wostern investigators. Nevortheless, the present observations aro of intorest to oncologists generally, particularly to those interested in the immunologioal aspects of cancer.

C. I. LEESE

\section{TRENDS IN CANCER RESEARCH}

\section{Advances in Cancer Research}

Vol. 7. Edited by Prof. Aloxander Haddow and Sidney Woinhouso. Pp. ix +599 . (Now York: Aoadomic l'ross, Inc.; London: Academic Press, Inc. (London), Ltd., 1963.) 128s. $6 d$.

\section{Canadian Cancer Conference}

Prococdings of tho Fifth Canidian Cancer Research Conference, Honey Harbour, Ontario, June 10-14, 1962. Edited by R. W. Begg, C. P. Leblond, R. L. Noblo, R. J. Rossitor, R. M. Taylor and A. C. Wallace. Pp. xii +479. (Now York: Academic Press, Tne.; London: Academic Press Ine. (London), Ltd., 1963.) 100s.

THE presont volumo of Advances in Cancer Research contains seven chapters. Beard discusses at considerable length our present knowledge of avian virus tumours, while Negroni, in $\mathrm{o}_{\mathrm{b}}$ shorter chapter, presents information about rabbit and mouse tumour virusos as woll as chicken tumour virusos and 'passenger' viruses, such as Riloy's Agent. In a long chapter, Brockmann deals with tho mechanisms of resistance to anti-concer agents, and quostions of cross-resistance and collaterel sensitivity in cancer chemotherapy are considered by Hutchinson. Theso chapters should be of ensiderable interest to workors diroctly concerned with virus tumours and chemotherapy.

Of moro general interest porhaps is an analysis by Kotin and Falk of tho contribution of atmospheric factors in the pathogenesis of eancer of the lung. Farber has surveyed tho carcinogenic properties of othionine and concludes that its activity may be due to its ability to produce altered DNA and/or RNA within the cell. At last, according to Farber, there is some fuctual support for hypotheses that altered chromosomal or extrachromosomal nucleic acids play a koy part in cancer production. In a short chapter, Court Brown and Tough present the interesting work of their group in Edinburgh and of a group of workers in Philadolphia on the discovery of an abnormal chromosome $\mathrm{Ph}^{1}$ in the marrow cells of patients with chronic myeloid leuktemia. 'This specific chromosomal abnormality seems to bo closoly connocted with the primary cause of the diseaso.

Volume 5 of the Camadian Cancer Conference prosents sets of papers devoted to collular organization, cell interaction, immunology and chemotherapy. The scope of this work is more gonoral than that of the present volume of Advances and it will probably appeal to a wider audience of enncor workers.

In the section on cellular organization, consideration is given to the modo of formation of polypeptide chains and to tho comparative molecular biology of virus and cellular nucleic acids. Autoradiographic investigations which doal with the sites of ribonucloic acid and protein synthesis in tho coll are presented, and Ochoa discusses the nature of the genetic codo. Interaction of viral ribonucloic acid with mammalian colls is doscribed, and Leslie donls with the control of gene expression which may be influenced by histonos. In in interesting discussion of ehromosomos and carcinogenesis Stich concludes that a genotic coneept of enncer must be given consideration, but the question still remains as to whether chromosomal changos in oarly neoplasia are cause or consequonce of cancer formation. 